i tym wszystkim, którzy interesują się problematyką przemian w polskiej rzeczywistości szkolnej.

\section{Violetta Rodek}

'Por. np. Cz. Majorek, Warsztat badawczy historyka wychowania dziejów najnowszych [w:] Stan i perspektywy historii wychowania, red. W. Jamrożek,
Poznań 1995, s. 63; S. Michalski, Geneza i rozwój historii wychowania [w:] Nauki pedagogiczne w Polsce, tradycja, wspótczesnośc, przyszłośc. Materiaty $z$ konferencji, red. S. Michalski i R. Ossowski, Bydgoszcz 1994, s. 20 - 21; B. Ratuś, Zwiazki historii i teorii wychowania (dylematy $w$ okresie zmiany ustroju $w$ Polsce) [w:] $Z$ problematyki metodologicznej teorii wychowania, red. A. Tchorzewski, Bydgoszcz 1994, s. 111 .

\title{
Adam Winiarz, Szkolnictwo Księstwa Warszawskiego i Królestwa Polskiego (1807-1831), Lublin 2002, ss. 586
}

Dzieje szkolnictwa w Księstwie Warszawskim i Królestwie Polskim doby konstytucyjnej stanowia jedną $\mathrm{z}$ najbardziej interesujących kart polskiej oświaty XIX wieku. Praca Adama Winiarza pt. „Szkolnictwo Księstwa Warszawskiego i Królestwa Polskiego (1807-1831)" jest pierwszą próbą tak szerokiego ujęcia tytułowego problemu. $O$ oryginalności i wyjatkowym charakterze pracy decyduje przede wszystkim fakt, iż omawiane przez autora zagadnienia nie posiadały dotąd pelnego opracowania monograficznego. Autor podjał się więc trudnego i mozolnego zadania ukazania złożonej problematyki szkolnictwa Księstwa Warszawskiego i Królestwa Polskiego doby autonomicznej.

Obszerny, bo liczacy 586 stron material ujęty został w 5 rozdziałach. W ich ramach autor prezentuje całość zawiłej problematyki szkolnej tego okresu.

Dodatkowym atutem pracy, uzupełniajacym zawarte w niej treści sa: streszczenie w języku angielskim, wykaz źródeł i literatury, indeks osób, indeks nazw geograficznych oraz wykaz skrótów używanych w tekście. Przypisy odnoszące się do treści poszczególnych rozdziałów, zapewne z uwagi na pokaźna ich liczbę, zostały umieszczone na końcu każdego $\mathrm{z}$ rozdziałów.

Precyzyjność i dociekliwość badawcza autora sprawiła, że recenzowana praca stanowi pod każdym względem dzieło dojrzałe i wiarygodne. O rzetelności przeprowadzonych badań świadczy niewatpliwie imponujący wręcz zasób źródel wykorzystany przez autora. $\mathrm{Z}$ uwagi na ich różnorodność zasługuja one na szersze omówienie.
Bazę źródłową opracowania stanowia materiały archiwalne, zarówno państwowych, jak i kościelnych archiwów z terenu Polski. Prezentowane w pracy źródła rękopiśmienne dowodza, iż autor przeprowadził również kwerendę zbiorów rękopiśmiennych bibliotek. Oprócz wspomnianych źródel, w pracy wykorzystane zostały liczne źródła drukowane, takie jak: Dzienniki Praw Księstwa Warszawskiego i Królestwa Polskiego, Dzienniki Departamentowe i Wojewódzkie, zbiory przepisów Izby Edukacyjnej, Komisji Rządowej Wyznań Religijnych i Oświecenia Publicznego, Komisji Rządowej Spraw Wewnętrznych i Policji oraz Komisji Rządowej Sprawiedliwości. Wykorzystano także programy popisów szkolnych z lat 1807 - 1835. Uzupełnieniem materiałów rękopiśmiennych i źródeł drukowanych jest prasa i czasopisma badanego okresu, podręczniki i książki używane w szkołach oraz literatura pamiętnikarska i wspomnieniowa.

Na uwage zasługuje także fakt, iż tytuły podręczników (także innych książek używanych w szkołach), programów popisów publicznych uczniów i ówczesnych drukowanych dokumentów zostały podane $w$ przypisach i bibliografii $z$ zachowaniem oryginalnej pisowni.

Obok walorów naukowych zaletą pracy jest również jej przejrzysty i logiczny układ. Autor trafnie zdecydował się nadać strukturze pracy uklad chronologiczno-problemowy, co pozwoliło na czytelne przedstawienie złożonej problematyki szkolnictwa Księstwa Warszawskiego i Królestwa Polskiego doby autonomicznej. 
Rozprawa składa się z 5 rozdziałów, podzielonych na mniejsze podrozdziały.

Rozdział I omawia proces ksztaltowania się centralnych i terenowych organów państwowej administracji szkolnej na tle wydarzeń politycznych. Przedstawiono tu również działalność dozorów szkolnych, rad departamentowych i wojewódzkich oraz scharakteryzowano źródła i zasady finansowania szkolnictwa. Wartość prezentowanych $w$ tym rozdziale zagadnień podnosi fakt, iż nie cieszyły się one jak dotąd większym zainteresowaniem historyków oświaty.

Kolejne cztery rozdziały zostały poświęcone poszczególnym szczeblom i typom szkolnictwa. W każdym $z$ nich przedstawiono i poddano analizie te same elementy, a mianowicie:

- genezę i organizację szkolnictwa (szkoły),

- bazę lokalowa,

- bazę dydaktyczna,

- programy i plany nauczania,

- kadrę nauczycielska, jej kształcenie,

- liczbę i pochodzenie społeczne uczniów (studentów),

- rezultaty działalności placówek danego szczebla (mierzone głównie liczbą absolwentów).

Rozdział II omawia pierwszy szczebel szkolnictwa - szkolnictwo elementarne. Przedstawione zostały w nim zagadnienia dotyczące organizacji i funkcjonowania szkolnictwa elementamego, szkól rzemieślniczo-niedzielnych, Instytutu Głuchoniemych oraz placówek publicznych dla dzieci żydowskich, a także kształcenie nauczycieli dla szkót elementarnych. Dziwić może fakt, iż to ostatnie zagadnienie (kształcenie nauczycieli dla szkół elementamych) zostało omówione w rozdziale II, mimo że $\mathrm{z}$ formalnego punktu widzenia seminaria (instytuty) nauczycielskie były szkołami zawodowymi. Jednak jak przekonuje nas sam autor, omówienie tej kwestii w tym rozdziale wydawało się bardziej zasadne ze względów merytorycznych ${ }^{1}$.

Rozdział III pracy poświęcony jest średniemu szkolnictwu męskiemu i żeńskiemu. Obok szkół departamentowych, wydziałowych i podwydziałowych, omówiono $w$ tym rozdziale również funkcjonujace $w$ tym okresie szkolnictwo prywatne. Tu również, przyjmując podobne założenie jak $\mathrm{w}$ rozdziale poprzednim, przedstawione zostało zagadnienie kształcenia nauczycieli. Warto podkreślić, że zarówno szkolnictwo męskie, jak i żeńskie nie doczekały się dotąd monograficz- nego opracowania. Jest to więc istonny głos w badaniach nad średnim szkolnictwem żeńskim i męskim w omawianym okresie.

W rozdziale IV pracy zostały ukazane $w$ ramach podziału szkolnictwa zawodowego na: cywilne, wojskowe i kościelne (seminaria duchowne) - Szkoła Akademiczno-Górnicza, Szkoła Szczególna Leśnictwa, Instytut Agronomiczny, Szkoła Przygotowawcza do Instytutu Politechnicznego, szkoły artystyczne (muzyczne i teatralne). Podobnie jak zagadnienia omawiane w rozdziałach II i III, żaden z przedstawionych $w$ tym rozdziale typów szkolnictwa nie posiada dotychczas swego monograficznego ujęcia ${ }^{2}$.

$\mathrm{W}$ rozdziale $\mathrm{V}$, ostatnim, przedstawione zostało szkolnictwo wyższe. Omówiono w tym rozdziale funkcjonowanie i organizację: Szkoły Prawa i Szkoły Nauk Administracyjnych, Szkoły Lekarskiej, Szkoły Głównej Krakowskiej i Uniwersytetu Warszawskiego.

Poznanie wielu szczegółów z dziedziny organizacji i funkcjonowania wymienionych placówek, włączonych następnie jako wydziały do utworzonego w 1816 r. Uniwersytetu Warszawskiego, jak zaznacza A. Winiarz, nie było możliwe z powodu zniszczenia materiałów archiwalnych. Poznanie i opracowanie problematyki szkolnictwa wyższego umożliwiła autorowi obszerna źródłowa monografia Józefa Bielińskiego ${ }^{3}$.

Po przeczytaniu rozprawy Adama Winiarza odnosi się wrażenie, że każdy z jej rozdziałów mógłby stanowić oddzielne opracowanie. Wynika to $\mathrm{z}$ pewnościa $\mathrm{z}$ bogactwa $\mathrm{i}$ wszechstronności przedstawianych zagadnień.

Sposób, w jaki autor przedstawił problem badawczy świadczy, iż z wielkim erudycyjnym wyczuciem porusza się on po niespenetrowanym jeszcze badawczo terenie.

Dzieło to, pomimo naukowego charakteru, można polecić nie tylko osobom zajmującym się nauka. $\mathrm{Z}$ uwagi bowiem na zamieszczone w pracy liczne cytaty z pamiętników i wspomnień, pozycja ta może zaciekawić również czytelnika niezorientowanego w podjętej $w$ rozprawie tematyce.

Szkoda, że nie udało się przedstawić dokładnej analizy programów i treści nauczania oraz podręczników, ale jak zaznaczył sam autor, wynika to z konieczności ograniczenia, i tak obszernej, objętości publikacji. Pozwala to jednak mieć nadzieję, iż w niedługim czasie autor pokusi się 
o opracowanie rozprawy poświęconej tym pominiętym, w recenzowanej pracy, zagadnieniom. $\mathrm{Z}$ cała pewnościa publikacja zawiera unikalne informacje, a wnioski z badań daja przyczynek do dalszych dyskusji, nie tylko nad dziejami szkolnictwa Księstwa Warszawskiego i Królestwa Polskiego (1807-1831), ale także nad szczeblami i typami szkolnictwa na ziemiach polskich w okresie zaborów.

\section{Grażyna Kartowska}

1 A. Winiarz, Szkolnictwo Księstwa Warszawskiego i Królestwa Polskiego (1807-1831), Lublin 2002, s. 11.

2 Jedyny syntetyczny zarys szkolnictwa zawodowego cywilnego interesujacego nas okresu przedstawil
Józef Miąso, Szkolnictwo zawodowe w Królestwie Polskim w latach 1815 - 1915, Wroclaw-Warszawa-Kraków 1966. Monograficznego ujęcia nie posiada szkolnictwo wojskowe. Praca, do której najczęściej odnosza się piszący o placówkach wojskowych jest praca B. Gembarzewskiego, Wojsko Polskie. Królestwo Polskie 1815-1830. Księstwo Warszawskie 1807-1814, Warszawa 1905. Podobnie jest z monografiami dotyczacymi seminariów duchownych omawianego okresu. Na uwagę zasługuja tu m.in. prace: J. Bielińskiego, Wydzial Teologiczny Królewskiego Warszaw'skiego Uniwersytetu (1817-1831). Zarys historyczny, Warszawa 1907; Seminarium Wtoctawskie. Szkic historyczny, na podstawie akt i dokumentów miejscowych ułożył i spisał ks. S. Chodyński, Wloclawek 1904.

${ }^{3}$ J. Bieliński, Królewski Uniwersytet Warszawski (1816-1831), Warszawa 1907, t. I; 1911, t. II; 1912, t. III.

\section{Dorota Żołądź-Strzelczyk, Wiesław Jamrożek, Studia z dziejów edukacji kobiet na ziemiach polskich, Agencja Wydawniczo-Po- ligraficzna „Bajt”, Poznań 2001, ss. 152}

Podjęty przez autorów temat mieści się w nurcie, podejmowanych już od pewnego czasu przez polskich historyków, badań poświęconych dziejom kobiet na ziemiach polskich. O ile sytuacja prawna czy biografie wybitnych kobiet doczekały się licznych opracowań ${ }^{1}$, to problematyka edukacji kobiet na ziemiach polskich nie została, jak dotad, w pełni opracowana.

Praca ta jest pod wieloma względami wyjatkowa $\mathrm{i}$ oryginalna. Nie każdy $\mathrm{z}$ nas bowiem uświadamia sobie jak długa droga i czas dzieli dzisiejsza wyemancypowana, wykształcona $\mathrm{j}$ aktywna w różnych dziedzinach życia spolecznego kobietę, od kobiety doby staropolskiej, wyposażonej częstokroć jedynie w podstawy wychowania domowego czy też niewiasty kształconej na popularnych w XVIII wieku pensjach. Autorzy pokusili się więc o przedstawienie kolejnych etapów pokonywanych w ewolucji oświatowej przez polską kobietę. Na uwagę zasługuje również fakt, iż materiał badawczy jest prezentowany w sposób przcjrzysty i czytelny, co obok walorów natury naukowej jest niewatpliwa zaleta dzieła.

Stworzony w prosty i logiczny sposób układ pracy sprawia, że czytelnik bez problemu odnajdzie interesujące go zagadnienia a jednocześnie zawarte w kolejnych rozdziałach treści sa ze soba harmonijnie połączone, tworząc spójną całość.

Język, jakim posługują się autorzy, w połączeniu $\mathrm{z}$ umiejętnym wyrażaniem stricte naukowych treści, gwarantuje szeroki krag odbiorców. Obok więc historyków czy studentów kierunków pedagogicznych i historycznych, adresatem prezentowanej publikacji może być każdy czytelnik zainteresowany kultura, tradycja i obyczajowościa.

Zarówno dla Doroty Żołądź-Strzelczyk, jak Wiesława Jamrożka prezentowana publikacja nie jest debiutem autorskim. Oboje maja już pewien dorobek badawczy. Czytelnicy systematycznie śledzacy publikacje z zakresu historii wychowania rozpoznaja w tym literackim duecie autorów innej pracy, również poświęconej kobiecie i edukacji $^{2}$.

Na pracę składa się materiał periodycznie podzielony na dwie części, z których pierwsza przedstawia Dzieje edukacji kobiet w Polsce przedrozbiorowej, natomiast część druga omawia Programy $i$ działalność edukacyjna kobiet polskich okresu niewoli.

Autorem części pierwszej jest Dorota Żołądź-Strzelczyk. W sześciu problemowo ułożonych rozdziałach autorka spogląda na kobietę 